Situs Jurnal : $\underline{\text { http://ejournal.stiepancasetia.ac.id/index.php/jieb }}$

Jilid 5 Nomor 3 November 2019

Hal 337 - 343

\title{
ANALISIS STRATEGI KUALITAS PELAYANAN UNTUK MENINGKATKAN KEPUASAN NASABAH PADA AXA MANDIRI INSURANCE CABANG A.YANI BANJARMASIN
}

\section{Nor Annisa*, Husnurrofiq, dan Apriya Santi}

Abstract: This study aims to: (1) Analyze whether service quality in the form of reliability, responsiveness, empathy, beliefs and direct evidence simultaneously affect customer satisfaction. (2) Analyzing whether service quality in the form of reliability, responsiveness, empathy, beliefs and direct evidence partially influences customer satisfaction. (3) Analyze the most dominant variables that affect customer satisfaction. With the purposive sampling method, there were 50 respondents. The analytical method used is multiple linear regression. The results of this study are: (1) Service quality in the form of reliability, responsiveness, empathy, beliefs and direct evidence simultaneously affected customer satisfaction by $44.7 \%$ while the remaining $55.3 \%$ was influenced by other variables. (2) Only empathy and belief that have a partial effect on customer satisfaction, while reliability, responsiveness and direct evidence have no partial effect on customer satisfaction. (3) Reliability is not a variable that has a dominant influence on customer satisfaction at AXA Mandiri Branch A. Yani Banjarmasin.

\section{Keywords: Service Quality, Customer Satisfaction}

Abstrak: Penelitian ini bertujuan untuk: (1) Menganalisis apakah kualitas jasa berupa keandalan, ketanggapan, empati, keyakinan dan bukti langsung secara simultan berpengaruh terhadap kepuasan nasabah. (2) Menganalisis apakah kualitas jasa berupa keandalan, ketanggapan, empati, keyakinan dan bukti langsung secara parsial berpengaruh terhadap kepuasan nasabah. (3) Menganalisis variabel yang paling dominan yang mempengaruhi kepuasan nasabah. Dengan metode purposive sampling, terdapat 50 responden. Metode analisis yang digunakan adalah regresi linier berganda. Hasil penelitian menunjukkan: (1) Kualitas jasa berupa keandalan, ketanggapan, empati, keyakinan dan bukti langsung secara simultan berpengaruh terhadap kepuasan nasabah dengan kekuatan pengaruh sebesar 44,7\% sedangkan sisanya yaitu 55,3\% dipengaruhi variabel lain. (2) Hanya empati dan keyakinan berpengaruh secara parsial terhadap kepuasan nasabah, sedangkan keandalan, ketanggapan dan bukti langsung tidak berpengaruh secara parsial terhadap kepuasan nasabah. (3) Keandalan bukan variabel yang berpengaruh dominan terhadap kepuasan nasabah pada AXA Mandiri Cabang A. Yani Banjarmasin.

Kata kunci: Kualitas Pelayanan, Kepuasan Nasabah

\section{Latar Belakang}

Kualitas pelayanan merupakan sebuah konsep integral yang dibangun dari kesadaran manajemen untuk memberikan pelayanan optimal pada setiap pelanggan yang menggunakan jasa perusahaan. Salah satu cara yang dilakukan oleh perusahaan yaitu mengukur tingkat kepuasan pelanggan adalah dengan memperhatikan dimensi kualitas jasa, sejauh mana tingkat kepuasan yang dirasakan pelanggan terhadap jasa yang diberikan oleh perusahaan sehingga 
akan didapatkan hasil yang menunjukkan apakah pelanggan yang dilayani merasa puas atau belum. Dalam pemasaran dikenal dimensi kualitas jasa yang terdiri dari lima dimensi yaitu: keandalan, ketanggapan, keyakinan, empati dan bukti langsung. Lima dimensi kualitas jasa ini bisa dijadikan acuan untuk mengukur kepuasan pelanggan akan pelayanan jasa yang diberikan oleh perusahaan. Maka penting sekali bagi perusahaan memaksimalkan pelayanan dan meningkatkan kualitas jasa yang mempengaruhi kepuasan pelanggan.

Kepuasan pelanggan terpenuhi apabila kualitas jasa sesuai dengan harapan. Sehingga untuk mengetahui seberapa besar kepuasan yang didapatkan pelanggan dalam pelayanan jasa yang diberikan perusahaan selama ini perlu dilakukan evaluasi. Pelanggan memang harus dipuaskan, karena jika mereka belum merasa puas oleh pelayanan yang diberikan, maka mereka akan meninggalkan perusahaan, sehingga hal ini akan menyebabkan pelanggan menjadi berkurang dan bisa menurunkan laba, dampak yang paling negatif akan menyebabkan perusahaan menderita kerugian. Salah satu persoalan yang harus dihadapi oleh AXA Mandiri adalah kualitas jasa yang dihasilkan oleh perusahaan tersebut, jika nasabah merasa tidak puas terhadap jasa yang telah diberikan oleh perusahaan maka akan membuat harapan nasabah akan jasa tersebut berkurang. Kinerja pelayanan yang tidak sesuai dengan harapan nasabah pada saat menggunakan produk atau jasa tentunya akan memicu terjadinya lost customer (kehilangan pelanggan) pada sebuah perusahaan. Dan jika hal itu terjadi maka perusahaan tersebut akan merugi. Dalam usaha insurance, AXA Mandiri sebagai bancassurance memiliki kewajiban untuk mengusahakan berbagai hal yang dapat mendukung tujuan tersebut, pentingnya hubungan antara tingkat kualitas jasa yang diberikan terhadap tingkat kepuasan karena perusahaan insurance yang dapat memenuhi kepuasan nasabahlah yang akan bertahan, maka untuk mengetahui kondisi perusahaan insurance ini, perlu dilakukan pengukuran tingkat kualitas insurance dalam hubungannya dengan kepuasan nasabah.

\section{Kajian Literatur}

Menurut Parasuraman et.al dalam Lupiyoadi dan Hamdani (2009), kualitas jasa dapat didefinisikan sebagai seberapa jauh perbedaan antara kenyataan dan harapan pelanggan atas pelayanan yang mereka terima. Pelanggan menilai kualitas jasa melalui lima dimensi sebagai berikut:

1. Keandalan yaitu kemampuan untuk melaksanakan jasa yang dijanjikan dengan tepat dan terpercaya. Keandalan mengukur keandalan dari perusahaan dalam memberikan pelayanan kepada pelanggannya.

2. Ketanggapan yaitu kemampuan untuk membantu pelanggan dan memberikan jasa dengan cepat atau ketanggapan. Ketanggapan adalah faktor kualitas jasa yang paling dinamis. Harapan pelanggan terhadap kecepatan pelayanan hampir dapat dipastikan akan berubah dengan kecenderungan pelayanan naik dari waktu ke waktu.

3. Empati yaitu syarat untuk peduli, memberi perhatian pribadi bagi pelanggan. Pelayanan empati memang sangat memerlukan sentuhan pribadi, tetapi sentuhan pribadi hanya dapat maksimal kalau perusahaan mempunyai sistem yang efektif. Tanpa hal ini, sungguh sulit untuk menerapkan pelayanan yang empati.

4. Keyakinan yaitu pengetahuan dan kesopanan karyawan serta kemampuan mereka untuk menimbulkan kepercayaan dan keyakinan.

5. Bukti Langsung yaitu penampilan fasilitas fisik, peralatan personel dan media komunikasi. Pelayanan tidak dapat dilihat, dicium dan tidak bisa diraba, maka aspek bukti langsung menjadi penting sebagai ukuran terhadap pelayanan (Lamb et.al 2000). 
Kepuasan adalah tingkat perasaan seseorang setelah membandingkan kinerja produk (atau hasil) yang ia rasakan dengan harapannya. Jadi tingkat kepuasan merupakan fungsi dari perbedaan antara kinerja yang dirasakan (perceived performance) dan harapan (expectations). Pelanggan bisa mengalami salah satu dari tiga tingkat kepuasan yang umum. Jika kinerja di bawah harapan, pelanggan akan tidak puas. Kalau kinerja sesuai dengan harapan, pelanggan akan puas. Apabila kinerja melampaui harapan, pelanggan akan sangat puas, senang, atau bahagia (Kotler, 2000).

Dari keseluruhan kegiatan yang dilakukan oleh sebuah perusahaan pada akhirnya akan bermuara pada nilai yang diberikan oleh pelanggan mengenai kepuasan yang dirasakan. Menurut Fornel dalam Lupiyoadi dan Hamdani (2009), banyak manfaat yang diterima oleh perusahaan dengan tercapainya tingkat kepuasan pelanggan yang tinggi. Tingkat kepuasan pelanggan yang tinggi dapat meningkatkan loyalitas pelanggan dan mencegah perputaran pelanggan, mengurangi sensitivitas pelanggan terhadap harga, mengurangi biaya kegagalan pemasaran, mengurangi biaya operasi yang diakibatkan oleh meningkatnya jumlah pelanggan, meningkatkan efektivitas iklan, dan meningkatkan reputasi bisnis.

Pada dasarnya kepuasan dan ketidakpuasan pelanggan atas produk akan berpengaruh pada pola perilaku selanjutnya. Hal ini ditunjukkan pelanggan setelah terjadi proses pembelian. Apabila pelanggan merasa puas, maka dia akan menunjukkan besarnya kemungkinan untuk kembali membeli produk yang sama. Pelanggan yang puas juga cenderung akan memberikan referensi yang baik terhadap produk kepada orang lain. (Kotler dalam Lupiyoadi dan Hamdani ,2009).

Ada beberapa penelitian terdahulu yang relevan dengan penelitian ini. Beberapa di antaranya adalah:

1. Risa Sasmita (2013), dengan judul "Pengaruh Kualitas Pelayanan Terhadap Kepuasan Nasabah (Studi pada Nasabah PT. Asuransi Jiwasraya (Persero) Malang Regional”. Teknik pengumpulan data dengan kuisioner, wawancara dan dokumentasi. Metode analisis dengan regresi linier berganda, uji bersama-sama dan uji parsial. Dari hasil penelitian diketahui bahwa variabel bebas yang terdiri dari Keandalan (X1), Daya Tanggap (X2), Jaminan (X3), Empati (X4), dan Bukti Fisik (X5) memiliki pengaruh signifikan terhadap variabel terikat yaitu Kepuasan Pelanggan (Y). Hasil uji parsial, dapat ditunjukkan bahwa variabel bebas yang terdiri dari Keandalan (X1), Daya Tanggap (X2), Jaminan (X3), Empati (X4), dan Bukti Fisik (X5) memiliki pengaruh signifikan terhadap variabel terikat yaitu Kepuasan Pelanggan (Y).

2. Vernando Satria Wijaya (2017), dengan judul "Pengaruh Kualitas Produk dan Persepsi Harga Terhadap Kepuasan Nasabah Melalui Kepercayaan Nasabah Asuransi Jiwasraya Cabang Kudus". Tujuan dari penelitian ini adalah untuk menguji dan menganalisis pengaruh Kualitas Produk dan Persepsi Harga terhadap PT. Asuransi Jiwasraya di Kudus. Metode pengumpulan data menggunakan kuesioner dan teknik analisis menggunakan Structural Equation Modeling kepada 203 responden. Teknik pengambilan sampel yang digunakan adalah purposive sampling. Hasil penelitian menunjukkan bahwa variabel kualitas produk dan persepsi harga adalah positif dan signifikan terhadap kepercayaan dan kepuasan pelanggan.

Berdasarkan dari permasalahan yang diangkat dalam penelitian ini dapat dirumuskan hipotesisnya sebagai berikut:

H1: Diduga kualitas jasa berupa keandalan, ketanggapan, empati, keyakinan dan bukti langsung secara simultan berpengaruh terhadap kepuasan nasabah pada AXA Mandiri Insurance Cabang A. Yani. 
H2: Diduga kualitas jasa berupa keandalan, ketanggapan, empati, keyakinan dan bukti langsung secara parsial berpengaruh terhadap kepuasan nasabah pada AXA Mandiri Insurance Cabang A. Yani.

H3: Diduga keandalan merupakan variabel yang paling dominan berpengaruh terhadap nasabah pada AXA Mandiri Insurance Cabang A. Yani.

\section{Metode Penelitian}

Jenis penelitian adalah penelitian kuantitatif. Karena data hanya dapat dikumpulkan dari nasabah AXA Mandiri maka metode yang dipilih adalah purposive sampling. Dengan mengambil 10-15\% dari jumlah populasi maka terdapat sebanyak 50 nasabah sebagai responden. Teknik pengumpulan data yang digunakan dalam penelitian ini yaitu observasi dan kuesioner dengan skala Sangat Tidak Setuju (STS)-Sangat Setuju (SS). Metode analisis yang digunakan adalah regresi linier berganda

\section{Hasil Penelitian}

Setelah melewati uji validitas dan reliabilitas, kemudian dilakukan Uji Asumsi Klasik yang menunjukkan hasil bahwa:

1. Uji Linearitas

Berdasarkan perhitungan uji linearitas diperoleh nilai $\mathrm{F}$ sebesar 0,772 dengan signifikansi 0,655 (di atas 0,05 ), berarti model regresi adalah linear.

2. Uji Normalitas

Berdasarkan hasil perhitungan uji normalitas diperoleh Sig $=0,059$. Dalam penelitian ini uji normalitas berdistribusi normal jika data memiliki probabilitas (sig) $>0,05$, dengan demikian hasil penelitian menunjukkan bahwa data berdistribusi normal karena probabilitas yang diperoleh $0,059>0,05$.

Langkah selanjutnya adalah proses Analisis Data dengan menggunakan alat analisis regresi linear berganda untuk mengetahui apakah kualitas jasa mempengaruhi kepuasan nasabah pada AXA Mandiri Cabang A. Yani maka dilakukan uji regresi berganda. Hal ini dapat dilihat pada tabel 1 .

Tabel 1. Analisis Regresi Berganda Pengaruh Kualitas Jasa Terhadap Kepuasan Pelanggan

\begin{tabular}{|c|c|c|c|c|}
\hline Variabel & Koefisien regresi & & Sig. & $\mathrm{r}_{\text {parsial }}$ \\
\hline \multicolumn{5}{|l|}{$\frac{\text { Variabel }}{\text { Variabel bebas }(\mathrm{X})}$} \\
\hline Keandalan $\left(\mathrm{X}_{1}\right)$ & 0,412 & 1,974 & 0,055 & 0,285 \\
\hline Ketanggapan $\left(\mathrm{X}_{2}\right)$ & 0,087 & 0,471 & 0,640 & 0,071 \\
\hline Empati $\left(\mathrm{X}_{3}\right)$ & 0,736 & 3,965 & 0,000 & 0,513 \\
\hline Keyakinan $\left(\mathrm{X}_{4}\right)$ & 1,330 & 3,645 & 0,001 & 0,482 \\
\hline Bukti Langsung $\left(\mathrm{X}_{5}\right)$ & 0,155 & 1,073 & 0,289 & 0,160 \\
\hline \multicolumn{5}{|l|}{ Variabel Terikat (Y) } \\
\hline \multicolumn{5}{|l|}{ Kepuasan Pelanggan } \\
\hline Konstanta & $=-11,723$ & $F_{\text {hitung }}$ & $=8,926$ & \\
\hline $\mathrm{R}$ & $=0,710$ & Sig. F & $=0,000$ & \\
\hline R. Square & $=0,504$ & $\mathrm{~F}_{\text {tabel }}$ & $=2,61$ & \\
\hline Adjusted R. Square & $=0,447$ & $t_{\text {tabel }}$ & $=2,68$ & \\
\hline Standar Deviasi & $=2,21671$ & SEE & $=2,21671$ & \\
\hline
\end{tabular}


Dari tabel 1 dapat diperoleh persamaan regresi sebagai berikut:

$Y=-11,723+0,412 X_{1}+0,087 X_{2}+0,736 X_{3}+1,330 X_{4}+0,155 X_{5}+e$.

Dari hasil Uji $\mathrm{F}$ diperoleh nilai Fhitung sebesar 8,926 dengan nilai probabilitas (sig) = 0,000 . Nilai Fhitung $(8,926)>$ Ftabel $(2,61)$, dan nilai signifikansi lebih kecil dari nilai probabilitas 0,05 atau $0,000<0,05$. Maka Hipotesis 1: Diduga kualitas jasa berupa keandalan, ketanggapan, empati, keyakinan dan bukti langsung secara simultan berpengaruh terhadap kepuasan nasabah pada AXA Mandiri Cabang A. Yani dapat diterima.

Berdasarkan hasil Uji t atas dapat dijelaskan pengaruh antara variabel $X$ terhadap variabel Y secara parsial untuk masing-masing variabel sebagai berikut:

1. Hasil uji menunjukkan bahwa untuk variabel keandalan (X1) thitung < ttabel atau 1,974< 2,68, berarti variabel keandalan (X1) tidak berpengaruh secara parsial terhadap kepuasan nasabah (Y).

2. Hasil uji menunjukkan bahwa untuk variabel ketanggapan (X2) thitung < ttabel atau 0,471 $<2,68$ berarti variabel ketanggapan (X2) tidak berpengaruh secara parsial terhadap kepuasan nasabah (Y).

3. Hasil uji menunjukkan bahwa untuk variabel empati (X3) terhadap thitung > ttabel atau $3,965>2,68$, berarti variabel empati (X3) berpengaruh secara parsial terhadap kepuasan nasabah $(\mathrm{Y})$.

4. Hasil uji menunjukkan bahwa untuk variabel keyakinan (X4) thitung > ttabel atau 3,645> 2,68 , berarti variabel keyakinan (X4) berpengaruh secara parsial terhadap kepuasan nasabah (Y).

5. Hasil uji menunjukkan bahwa untuk variabel bukti langsung (X5) thitung < ttabel atau 1,073 $<2,68$, berarti variabel bukti langsung $(\mathrm{X} 4)$ tidak pengaruh secara parsial terhadap kepuasan nasabah (Y).

Maka dapat disimpulkan Hipotesis 2: Diduga kualitas jasa berupa keandalan, ketanggapan, empati, keyakinan dan bukti langsung secara parsial berpengaruh terhadap kepuasan nasabah pada AXA Mandiri Cabang A. Yani ditolak karena hanya variabel empati dan variabel keyakinan yang berpengaruh signifikan terhadap kepuasan nasabah.

Di antara variabel bebas yang mempunyai pengaruh paling dominan mempengaruhi kepuasan nasabah AXA Mandiri Cabang A. Yani adalah variabel empati karena memiliki $r$ parsial 0,513 lebih besar daripada $r$ parsial variabel lainnya. Berarti Hipotesis 3 yang menyatakan bahwa Diduga keandalan merupakan variabel yang paling dominan berpengaruh terhadap kepuasan nasabah pada AXA Mandiri Cabang A. Yani Ditolak karena keandalan bukan merupakan variabel yang dominan pengaruhnya terhadap kepuasan nasabah AXA Mandiri Cabang A. Yani sebab r parsial keandalan hanya sebesar 0,285 sementara variabel yang mempunyai pengaruh dominan terhadap kepuasan pelanggan adalah empati dengan nilai r parsial sebesar 0,513.

\section{Diskusi}

Poin-poin penting dari penelitian ini adalah sebagai berikut:

1. Pengaruh seluruh variabel bebas (X) terhadap variabel terikat (Y) adalah $44,7 \%$. Sedangkan sisanya yaitu 55,3\% dipengaruhi variabel lain seperti harga yang merupakan strategi dalam 
pemberian nilai kepada nasabah dan mempengaruhi keputusan pembelian nasabah, lokasi yang mudah dijangkau dan strategis yang tidak diteliti dalam penelitian ini, sehingga kualitas jasa berupa keandalan, ketanggapan, empati, keyakinan dan bukti langsung secara simultan berpengaruh terhadap kepuasan pelanggan pada AXA Mandiri Cabang A. Yani dapat diterima dan hal ini perlu menjadi perhatian pihak manajemen AXA Mandiri Cabang A.Yani Banjarmasin untuk terus meningkatkan kualitas jasa yang mereka berikan terhadap nasabah.

2. Pengaruh variabel empati terhadap kepuasan nasabah. Berdasarkan hasil uji bahwa variabel empati berpengaruh secara parsial terhadap kepuasan dengan kontribusi sebesar 26,3\% terhadap kepuasan nasabah. Empati merupakan kemampuan karyawan AXA Mandiri Cabang A. Yani dalam memberikan perhatian, seperti keramahan karyawan, perhatian karyawan, komunikasi yang dilakukan karyawan. Nasabah menilai kualitas jasa melalui empati yaitu syarat untuk peduli, memberi perhatian pribadi bagi nasabah. Hal ini berarti perusahaan memberikan perhatian yang memuaskan nasabah, sebab semakin tinggi empati atau perhatian yang diperlihatkan oleh para karyawan maka akan mempengaruhi kepuasan nasabah.

3. Pengaruh variabel keyakinan terhadap kepuasan nasabah. Berdasarkan hasil uji bahwa variabel keyakinan berpengaruh secara parsial terhadap kepuasan dengan kontribusi variabel keyakinan sebesar 23,2\% terhadap kepuasan nasabah. Keyakinan merupakan pelaksanaan dan tanggung jawab karyawan AXA Mandiri Cabang A.Yani dalam meyakinkan nasabah, seperti meyakinkan nasabah mendapatkan kemudahan akses informasi lebih baik, meyakinkan nasabah tarif premi sesuai dengan produk yang ditawarkan, meyakinkan nasabah tidak dikenakan lagi biaya-biaya lain dalam pengurusan klaim. Nasabah menilai kualitas jasa melalui keyakinan yaitu pengetahuan dan kesopanan karyawan serta kemampuan mereka untuk menimbulkan kepercayaan dan keyakinan. Hal ini berarti perusahaan memberikan keyakinan yang belum begitu memuaskan bagi nasabah, sebab semakin tinggi karyawan memberikan keyakinan kepada nasabah maka akan mempengaruhi kepuasan nasabah.

4. Variabel yang mempunyai pengaruh dominan terhadap kepuasan pelanggan adalah empati. Hal ini berarti bahwa perhatian karyawan AXA Mandiri Cabang A. Yani terhadap nasabah dengan cara memberikan pelayanan dengan ramah, memberikan perhatian kepada nasabah, dan karyawan menjalin komunikasi yang lancar, sehingga bagi nasabah empati merupakan faktor yang dominan dalam menentukan kepuasan mereka. Artinya nasabah AXA Mandiri Cabang A. Yani menilai empati yang diberikan karyawan sangat baik yaitu keramahan karyawan, perhatian karyawan, komunikasi karyawan kepada nasabah.

\section{Kesimpulan dan Keterbatasan Penelitian}

Terdapat beberapa kesimpulan dari penelitian ini. Kesimpulan dari penelitian ini dapat dijabarkan sebagai berikut:

1) Kualitas jasa berupa keandalan, ketanggapan, empati, keyakinan dan bukti langsung secara simultan berpengaruh terhadap kepuasan nasabah pada AXA Mandiri Cabang A. Yani Banjarmasin.

2) Empati dan keyakinan berpengaruh secara parsial. Sedangkan variabel keandalan, ketanggapan dan bukti langsung tidak berpengaruh secara parsial terhadap kepuasan nasabah pada AXA Mandiri Cabang A. Yani Banjarmasin.

3) Empati adalah variabel yang berpengaruh dominan terhadap kepuasan nasabah pada AXA Mandiri Cabang A. Yani Banjarmasin. 
Saran dari penelitian ini adalah:

1. Variabel empati adalah variabel yang dominan berpengaruh terhadap kepuasan nasabah pada perusahaan AXA Mandiri Cabang A. Yani, maka hendaknya AXA Mandiri Cabang A. Yani mempertahankan dan meningkatkan variabel empati tersebut agar kepuasan nasabah tetap terjaga, misalnya dengan cara lebih meningkatkan komunikasi yang baik dan ramah.

2. Bagi peneliti selanjutnya sangatlah penting mengembangkan penelitian ini sehingga mampu menghasilkan temuan yang lebih tajam dan mendalam demi kesempurnaan penelitian ini.

\section{DAFTAR PUSTAKA}

Arikunto, Suharsimi, 2006, Prosedur Penelitian Suatu Pendekatan dan Praktek, Rineka Cipta, Jakarta.

Cecep Supriyadi, “AXA Mandiri, Perusahaan Asuransi Terbaik 2014”, Portal Marketing, diakses dari www.marketing.co.id/axa-mandiri-perusahaan-asuransi-terbaik-2014, tanggal 2102/2019.

J. Supranto, 1997. Pengukuran Tingkat Kepuasan Pelanggan Untuk Menaikkan Pangsa Pasar. Jakarta: Rineka Cipta.

Kotler, Philip 1997. Manajemen Pemasaran, Edisi Bahasa Indonesia Jilid 2. PT. Ikrar Mandiri Abadi, Jakarta.

Kotler, Philip dan KevinLane Keller, 2009, Alih Bahasa: Benyamin Molan, Manajemen Pemasaran, Edisi Ketigabelas Jilid 1 Cetakan Keempat, Jakarta, PT. Indeks.

Lamb Hair. Mc Daniel, 2000, Pemasaran, Buku 1, Salemba Empat, Jakarta.

Lupiyoadi, Rambat dan A. Hamdani. 2009. Manajemen Pemasaran Jasa. Salemba Empat, Jakarta.

Ratnasari, Ririn Tri dan Mastuti H. Aksa, 2011, Manajemen Pemasaran Jasa, Bogor: Ghalia Indonesia.

Risa Sasmita. 2013. Pengaruh Kualitas Pelayanan Terhadap Kepuasan Nasabah (Studi pada Nasabah PT. Asuransi Jiwasraya (Persero) Malang Regional. Abstrak. Fakultas Ilmu Administrasi Universitas Brawijaya Malang.

Sugiyono, 2004, Metode Penelitian Bisnis, Bandung: Penerbit Alfabeta.

Tjiptono, Fandy, 1996. Manajemen Jasa. Yogyakarta: Andi.

Umar, Husein, 2003. Riset Pemasaran dan Perilaku Konsumen. Jakarta: PT. Gramedia Pustaka Utama Bekerjasama dengan Jakarta Business Research Center (JBRC).

Vernando Satria Wijaya (2017). Pengaruh Kualitas Produk Dan Persepsi Harga Terhadap Kepuasan Nasabah Melalui Kepercayaan Nasabah Asuransi Jiwasraya Cabang Kudus. Magister Manajemen, Fakultas Ekonomi dan Bisnis, Universitas Dian Nuswantoro. Jurnal Penelitian Ekonomi dan Bisnis, 2 (2), 2017. 